\title{
Lecithins from Vegetable, Land, and Marine Animal Sources and Their Potential Applications for Cosmetic, Food, and Pharmaceutical Sectors
}

\author{
Maria J. Alhajj ${ }^{\circledR}$, Nicolle Montero ${ }^{\circledR}$, Cristhian J. Yarce $\mathbb{D}^{\circledR}$ and Constain H. Salamanca * \\ Laboratorio de Diseño y Formulación de Productos Químicos y Derivados, Departamento de Ciencias \\ Farmacéuticas, Facultad de Ciencias Naturales, Universidad ICESI, Calle 18 No. 122-135, 760035 Cali, Colombia; \\ mariajoalhajj@hotmail.com (M.J.A.); nicollemontero76@gmail.com (N.M.); cjyarce@icesi.edu.co (C.J.Y.) \\ * Correspondence: chsm70@gmail.com; Tel.: +57-312-223-8310
}

Received: 29 September 2020; Accepted: 4 November 2020; Published: 9 November 2020

\begin{abstract}
The aim of this work was to review the reported information about the phospholipid composition of lecithins derived from several natural sources (lipids of plant, animal, and marine origin) and describe their main applications for the cosmetic, food, and pharmaceutical sectors. This study was carried out using specialized search engines and according to the following inclusion criteria: (i) documents published between 2005 and 2020, (ii) sources of lecithins, (iii) phospholipidic composition of lecithins, and (iv) uses and applications of lecithins. Nevertheless, this work is presented as a narrative review. Results of the review indicated that the most studied source of lecithin is soybean, followed by sunflower and egg yolk. Contrarily, only a few numbers of reports focused on lecithins derived from marine animals despite the relevance of this source in association with an even higher composition of phospholipids than in case of those derived from plant sources. Finally, the main applications of lecithins were found to be related to their nutritional aspects and ability as emulsion stabilizers and lipid component of liposomes.
\end{abstract}

Keywords: lecithin; phospholipids; nutritional value; emulsion stabilizer; lecithin-based liposomes

\section{Introduction}

Lecithin is a generic term that is used for the description of a multi-component blend of lipids (triglycerides, fatty acids, sterols, glycolipids, and phospholipids) [1], which are structural and functional components of a diverse range of cell membranes for plants as well as for various terrestrial and marine animals [2]. Although lecithin is present in most living organisms, their chemical (lipid composition) and physical (sensory appearance) characteristics can vary considerably, depending on the origin and the extraction process. In this way, depending on the class and quantity of phospholipids as well as their purity grade, lecithin can be used as a product or raw material. Consequently, lecithins describe a wide variety of compounds based on their composition (type and amount of lipids) as well as their appearance, which can range from a sticky paste to fluid granules with different grades of purity $[3,4]$. The procedures that are carried out after obtaining the lecithins can be classified into three categories, including (i) natural or unrefined, (ii) refined, as well as (iii) modified lecithins [5]. Natural lecithins do not undergo any treatment or modification process after they are obtained. This category is the primary focus of this review. On the other hand, refined lecithins include oil-free lecithins as well as alcohol-soluble/insoluble phospholipids fractions [6], whereas modified lecithins are those in which the polar group of the phospholipids is chemically changed by acetylation, hydroxylation, or enzymatic modification processes [5].

Concerning the composition of lecithins, they consist of two kinds of phospholipids (PLs): sphingophospholipids and glycerophospholipids (GPLs). The latter category includes those that 
are the focus of this review as previous studies showed a diverse range of their applications for the cosmetic, foodstuff, and pharmaceutical sectors [7]. Regarding the structural composition of GPLs, these are composed of a glycerol backbone, two alkyl chains made of fatty acids $\left(R_{1}\right.$ and $\left.R_{2}\right)$, and a phosphate group linked to different types of substitutes $(Y)$, which determine the functionality of the phospholipid (Figure 1) [8,9].

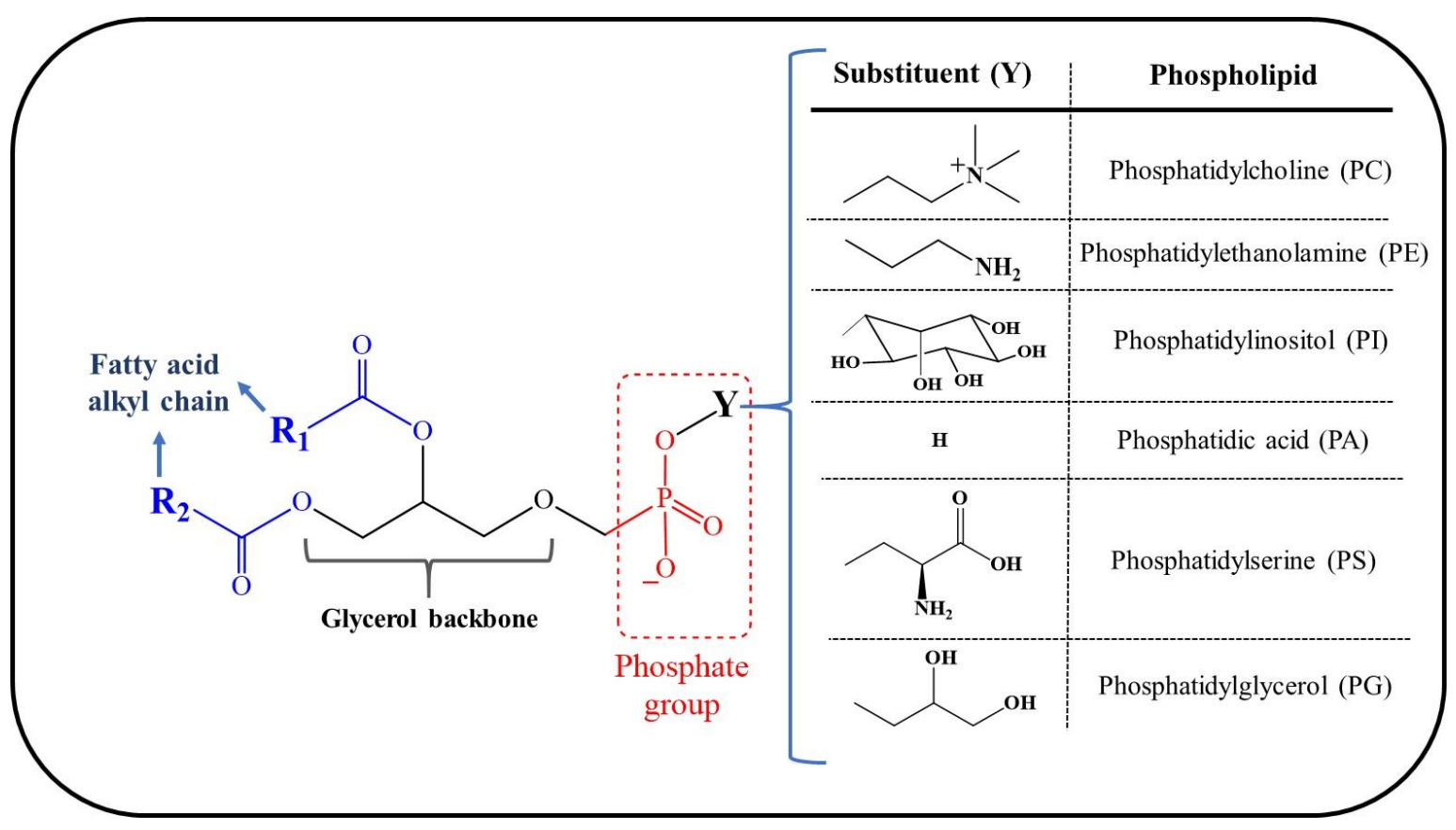

Figure 1. The chemical structure and classification of the different types of glycerophospholipid lecithins.

Furthermore, many of these GPLs were previously characterized, proving to have nutritional value, high biocompatibility, and an amphiphilic character, which are characteristics highly appreciated in various industrial sectors, such as cosmetics, food, and pharmaceuticals [10-12]. Regarding the amphiphilic character, this can be considered as a highly relevant property as it allows the application of lecithins as humectant systems, emulsion stabilizers, as well as the lipid component of liposomes [1].

The phospholipid composition of lecithins can vary considerably depending on the source (vegetable or animal) as well as the obtention methodology. However, to date, only a handful of reviews have focused on the description of the phospholipid composition of lecithins derived from different natural sources, and even more, on descriptions including their applications in different industrial sectors. Therefore, this review focuses on providing updated information on two essential aspects: (i) The phospholipid composition of lecithins derived from several natural sources (plants, land animals, and marine animals) and (ii) the use and application of lecithins as nutritional ingredients, emulsion stabilizers, and structural components of liposomes, which are very relevant for the cosmetic, foodstuff, and pharmaceutical sectors.

\section{Information Search Methodology}

This review manuscript was carried out according to the preferred reporting items for systematic reviews and meta-analyses (PRISMA) guidelines, as recommended by Cosmetics journal. For this, five specialized databases were used for information search, where a total of 2563 documents were identified and analyzed. The applied search algorithm as well as identified results are presented in Figures 2 and 3. It is important to highlight that the document is presented as a narrative review, including the search algorithm mentioned before. 


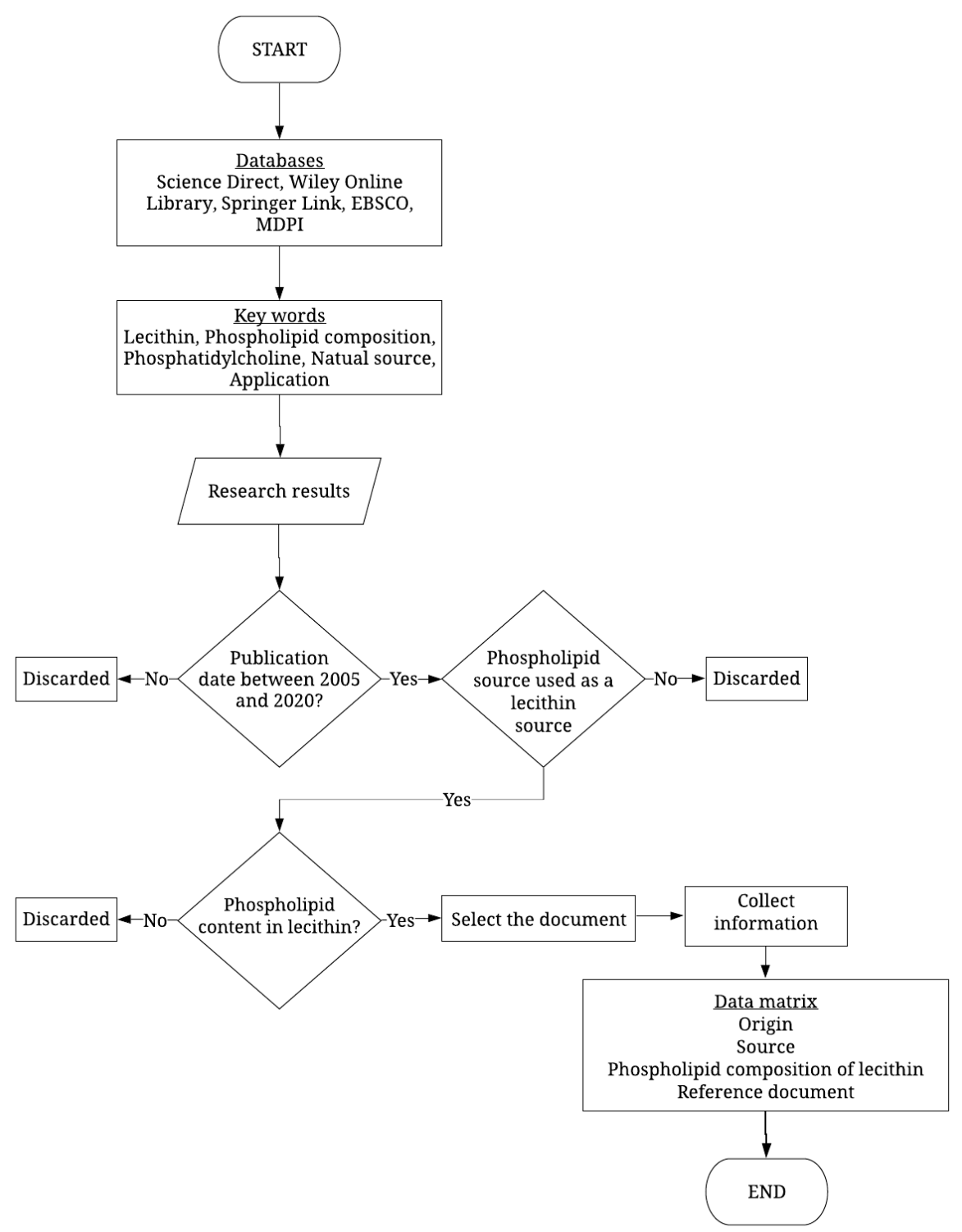

Figure 2. Flowchart showing the information on the search methodology. 


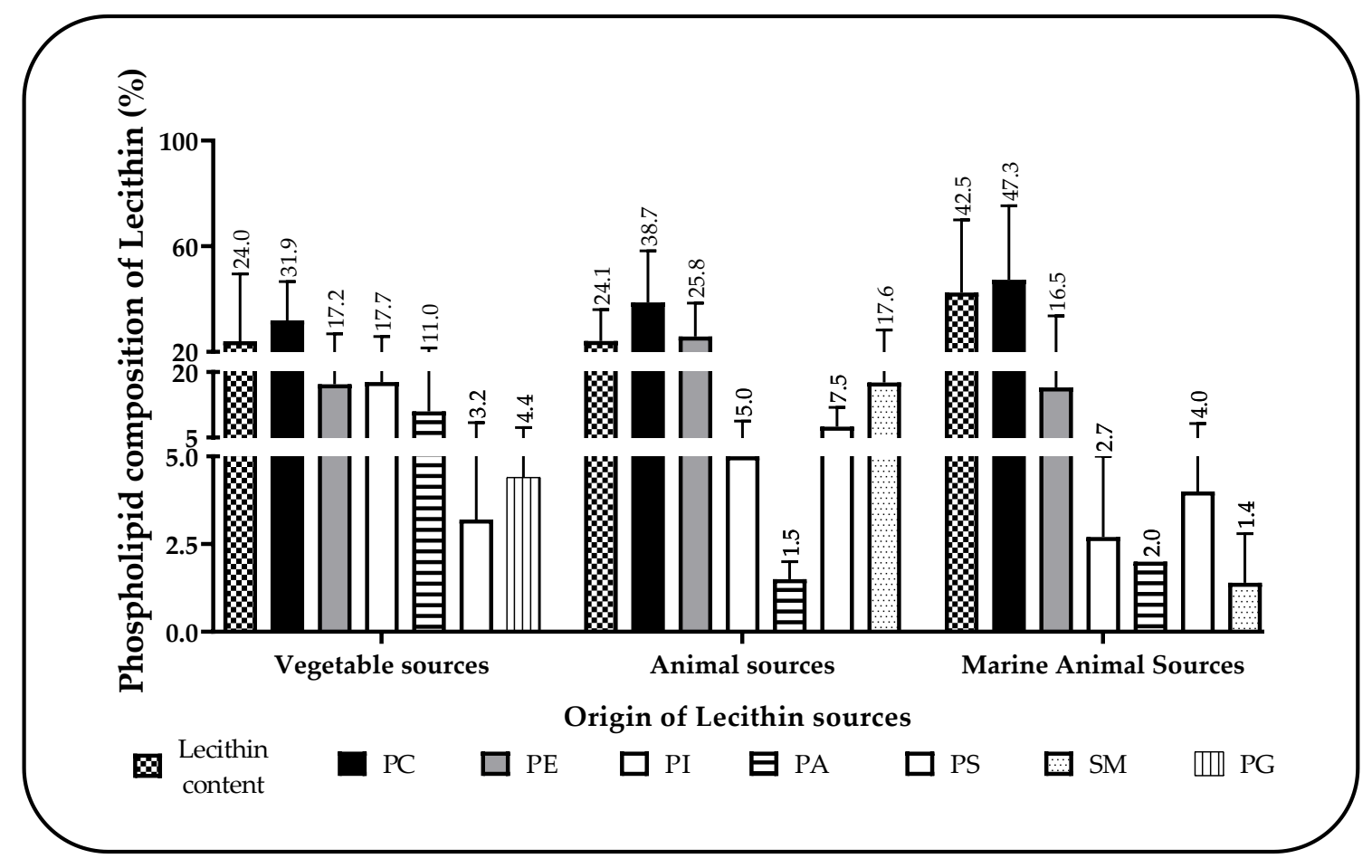

Figure 3. Average composition of phospholipids depending on the origin (lecithin content: fraction of polar lipids in the studied source, PC: Phosphatidylcholine, PE: Phosphatidylethanolamine, PI: Phosphatidylinositol, PA: Phosphatidic acid, PS: Phosphatidylserine, SM: Sphingomyelin, PG:

Phosphatidylglycerol).

For the search, five databases with reliable scientific information were used: Science Direct (available online: sciencedirect.com accessed on 9 June 2020), Wiley Online Library (available online: onlinelibrary.wiley.com, accessed on 9 June 2020), Springer Link (available online: link.springer.com, accessed on 9 June 2020), EBSCO (available online: web.b.ebscohost.com, accessed on 9 June 2020). and MDPI (available online: mdpi.com accessed on 9 June 2020) The used keywords were "Lecithin, Phospholipid composition, Phosphatidylcholine, Natural source, Application". In addition, 3 selection criteria were established to narrow the search and obtain relevant results: (i) documents published between 2005 and 2020, (ii) source of lecithin and lecithins phospholipidic composition, and (iii) uses and applications of lecithin. Finally, the selected documents were analyzed, and the information was organized in a data matrix compiling the origin, source, phospholipid composition, and reference; likewise, the data were summarized using a dynamic Excel table, which facilitated its analysis.

\section{Phospholipid Composition of Lecithins}

The reported information regarding the phospholipid content of lecithins derived from different origins and natural sources is summarized in Tables $1-3$. 
Table 1. The phospholipid composition of natural lecithins derived from vegetable sources.

\begin{tabular}{|c|c|c|c|c|c|c|c|}
\hline \multirow{2}{*}{ Origin of Lecithin Sources/References } & \multirow{2}{*}{$\begin{array}{l}\text { Lecithin } \\
\text { Content }\end{array}$} & \multicolumn{6}{|c|}{ Phospholipid Composition of Lecithins (\%) } \\
\hline & & PC & PE & PI & PA & PS & PG \\
\hline Vegetable Sources & $0.7-1.9$ & $3.2-74.9$ & $3.0-64.9$ & $1.1-41.0$ & $0.2-43.0$ & $0.2-26.0$ & $0.9-9.0$ \\
\hline Soybean/[3,13-35] & $60.0-81.9$ & $10.0-55.3$ & $6.5-34.0$ & $1.7-41.0$ & $0.2-12.0$ & $0.2-6.0$ & $1.0-2.0$ \\
\hline Soybean */[10,36] & & $10.0-55.0$ & $9.0-26.0$ & $8.0-18.0$ & - & - & $1.0-2.0$ \\
\hline Sunflower/[16,17,21,23-25,28,30,33,35,37-39] & $38.9-43.1$ & $14.0-64.0$ & $4.8-24.0$ & $11.0-35.7$ & $1.3-13.0$ & $1.0-4.0$ & $0.9-1.0$ \\
\hline Sunflower */[29] & & $12.7-64.2$ & $9.9-46.6$ & $3.7-36.0$ & - & - & - \\
\hline Rapeseed/[3,13,16,21,23-25,28,30,33,35,40] & $71.3-71.3$ & $16.7-74.1$ & $6.5-64.9$ & $5.3-33.0$ & $2.4-28.0$ & $1.0-4.0$ & \\
\hline Rapeseed */[29] & & $16.2-24.6$ & $12.0-22.1$ & $7.6-18.0$ & - & - & - \\
\hline Corn/[21,23,29,33,41,42] & $57.5-68.1$ & $30.0-68.1$ & $3.0-13.9$ & $14.5-19.8$ & $9.0-9.4$ & 1.0 & $1.0-1.4$ \\
\hline Rice bran/[21,43-45] & $33.0-33.6$ & $3.2-38.0$ & $11.8-33.2$ & $5.8-19.7$ & $2.5-22.6$ & & $8.6-8.6$ \\
\hline Rice bran */[29] & & $20.4-23.1$ & $17.8-20.2$ & $5.8-6.6$ & & & \\
\hline Cottonseed/[29] & & $23.2-35.9$ & 13.5-20.1 & $13.4-13.4$ & 8.8 & $2.4-26.0$ & 7.6 \\
\hline Cottonseed $* /[46]$ & & 33.0 & 22.0 & 37.0 & & & \\
\hline Barley */[29] & & $44.3-44.4$ & $7.6-8.8$ & $1.1-1.3$ & & & \\
\hline Flaxseed/[47] & $4.8-7.8$ & $31.0-37.0$ & $12.0-16.0$ & $24.0-31.0$ & $16.0-23.0$ & & \\
\hline Jangli badam seed */[29] & & 30.0 & 23.0 & 40.6 & & & \\
\hline Palash seed */[29] & & 44.6 & 14.8 & 27.0 & & & \\
\hline Papaya seed */[29] & & 28.1 & 18.7 & 34.0 & & & \\
\hline Peanut/[33,48] & & $23.0-39.4$ & $8.0-18.8$ & $17.0-22.2$ & $2.0-6.6$ & & \\
\hline Peanut */[29] & & 49.0 & 16.0 & 22.0 & & & \\
\hline Sesame/[47] & $0.7-3.0$ & 39.0 & $10.0-19.0$ & $13.0-14.0$ & $27.0-30.0$ & & \\
\hline Cacao Beans [49] & & $36.0-40.0$ & $11.0-19.0$ & $26.0-29.0$ & $7.0-10.0$ & $2.3-3.3$ & \\
\hline Carrot seed */[29] & & 29.1 & 35.4 & 23.1 & & & \\
\hline
\end{tabular}


Table 1. Cont

\begin{tabular}{|c|c|c|c|c|c|c|c|}
\hline \multirow{2}{*}{ Origin of Lecithin Sources/References } & \multirow{2}{*}{$\begin{array}{l}\text { Lecithin } \\
\text { Content }\end{array}$} & \multicolumn{6}{|c|}{ Phospholipid Composition of Lecithins (\%) } \\
\hline & & PC & PE & PI & PA & PS & PG \\
\hline Coriander seed */[29] & & 44.0 & 29.3 & 23.1 & & & \\
\hline Oats/[50] & $5.0-26.0$ & $45.0-50.0$ & 9.0 & 10.0 & 18.0 & & \\
\hline Durum Wheat */[51] & $6.1-14.1$ & 26.4 & 25.5 & 27.3 & & & 4.5 \\
\hline Wheat germ/[52] & & $40.0-60.0$ & $9.0-15.0$ & $13.0-20.0$ & & & \\
\hline Walnut/[47] & $8.1-10.8$ & 23.0 & $13.0-16.0$ & $24.0-26.0$ & $34.0-38.0$ & & \\
\hline Niger Seed Oil/[53] & & 48.7 & 22.5 & 14.6 & & 8.7 & \\
\hline Avocado fruit */[29,54] & & $20.0-44.9$ & $12.0-55.0$ & $12.1-18.0$ & & & \\
\hline Olive fruit */[29] & & $47.3-58.9$ & $5.3-8.0$ & $18.0-23.9$ & & & \\
\hline Garlic/[55] & 23.4 & 23.5 & 17.9 & & & & \\
\hline Palm/[56] & 10.0 & 36.0 & 24.0 & 22.0 & 3.0 & & 9.0 \\
\hline Palm */[57] & & $34.0-35.0$ & $22.0-26.0$ & $21.0-25.0$ & & & \\
\hline Cucurbirt */[29] & & $55.8-74.9$ & $10.5-18.7$ & $13.7-17.2$ & & & \\
\hline Camelina/[47] & $6.3-10.4$ & $17.0-21.0$ & $12.0-16.0$ & $13.0-25.0$ & $42.0-43.0$ & & \\
\hline Hemp/[47] & $3.9-6.5$ & $44.0-45.0$ & $15.0-17.0$ & $21.0-25.0$ & $9.0-12.0$ & & \\
\hline Xanthoceras sorbifolium/[58] & & $9.7-19.1$ & $5.6-7.0$ & $13.9-29.1$ & $24.2-34.1$ & & $3.3-7.3$ \\
\hline
\end{tabular}

${ }^{*}$ It is not established if the reported percentage corresponds to the whole lipidic fraction of the lecithin. PC (Phosphatidylcholine), PE (Phosphatidylethanolamine), PI (Phosphatidylinositol), PA (Phosphatidic acid), PS (Phosphatidylserine), and PG (Phosphatidylglycerol). 
Table 2. Phospholipid composition of natural lecithins from animal sources.

\begin{tabular}{|c|c|c|c|c|c|c|c|}
\hline \multirow{2}{*}{ Origin of Lecithin Sources/References } & \multirow{2}{*}{$\begin{array}{l}\text { Lecithin } \\
\text { Content }\end{array}$} & \multicolumn{6}{|c|}{ Phospholipid Composition of Lecithins (\%) } \\
\hline & & PC & PE & PI & PA & PS & SM \\
\hline Animal Sources & $8.0-50.0$ & $8.0-82.0$ & $1.9-72.3$ & $0.0-14.1$ & $0.9-2.0$ & $1.0-18.0$ & $1.0-35.3$ \\
\hline Egg yolk/[14,23,24,26,27,29,33,36,59-63] & $8.0-50.0$ & $60.0-82.0$ & $8.0-26.0$ & $0.0-3.0$ & 1.0 & $1.0-3.0$ & $1.0-6.0$ \\
\hline Egg yolk */[10,28,64] & & $65.0-70.0$ & $9.0-13.0$ & & & & \\
\hline Duck egg yolk/[65] & & $20.4-21.0$ & $4.3-4.8$ & 0.5 & & & \\
\hline Goose egg yolk/[65] & & $22.5-23.1$ & $3.2-3.5$ & $0.4-0.5$ & & & \\
\hline Quail egg yolk/[65] & & $33-33.5$ & $3.7-3.9$ & 0.3 & & & \\
\hline Turkey egg yolk/[65] & & $28.9-30.0$ & $3.6-4.1$ & $0.3-0.4$ & & & \\
\hline Ostrich egg yolk/[65] & & $30.7-31.9$ & $1.9-2.3$ & 0.6 & & & \\
\hline Milk/[14,23,27,66,67] & $9.4-40.0$ & $19.2-37.3$ & $19.8-42.0$ & $0.6-11.8$ & 2.0 & $1.9-12.0$ & $25.2-29.0$ \\
\hline Milk */[10] & & 26.0 & 30.0 & 9.0 & & & \\
\hline Milk fat/[68] & & $8.0-45.5$ & $26.4-72.3$ & $1.4-14.1$ & & $2.0-16.1$ & $4.1-29.2$ \\
\hline Cow's milk/[24] & & $20.0-30.0$ & $28.0-35.0$ & & & $1.0-8.0$ & \\
\hline Cow's milk*/[60,69,70] & & $19.1-40.0$ & $19.8-42.0$ & $0.6-12.0$ & & $1.9-11.2$ & $18.0-35.3$ \\
\hline Ewes' milk */[60] & & $26.0-28.0$ & $26.0-40.0$ & $4.0-7.0$ & & $4.0-11.0$ & $22.0-30.0$ \\
\hline Goat milk*/[60] & & $27.0-32.0$ & $20.0-42.0$ & $4.0-10.0$ & & $3.0-14.0$ & $16.0-30.0$ \\
\hline Bovine milk fat/[71] & & & $27.5-32.9$ & & & $6.3-8.3$ & $26.3-28.5$ \\
\hline Bovine brain/[24,33] & & $18.0-43.0$ & $18.0-36.0$ & $1.0-7.0$ & $1.0-2.0$ & $9.0-18.0$ & 15.0 \\
\hline Bovine brain */[29] & & $18.4-48.2$ & $23.5-36.1$ & $1.8-7.1$ & $0.9-1.7$ & $6.7-18.0$ & \\
\hline
\end{tabular}

${ }^{*}$ It is not established if the reported percentage corresponds to the whole lipidic fraction of the lecithin. PC (Phosphatidylcholine), PE (Phosphatidylethanolamine), PI (Phosphatidylinositol),

PA (Phosphatidic acid), PS (Phosphatidylserine), and SM (Sphingomyelin). 
Table 3. Phospholipid composition of natural lecithins from marine animal sources.

\begin{tabular}{|c|c|c|c|c|c|c|c|}
\hline \multirow{2}{*}{ Origin of Lecithin Sources } & \multirow{2}{*}{$\begin{array}{l}\text { Lecithin } \\
\text { Content }\end{array}$} & \multicolumn{6}{|c|}{ Phospholipid Composition of Lecithins (\%) } \\
\hline & & PC & PE & PI & PA & PS & SM \\
\hline Marine Animal Sources & $8.9-91.6$ & $4.1-81.2$ & $2.0-67.4$ & $0.7-7.0$ & 2.0 & $1.0-7.0$ & $0.2-3.0$ \\
\hline Salmon/[13,70] & 61.1 & 33.0 & & & & & \\
\hline Salmon */[60] & & $50.0-62.0$ & $10.0-40.0$ & $5.0-7.0$ & & $1.0-7.0$ & $0.2-1.0$ \\
\hline Salmon egg */[60,72] & 35.0 & $29.0-80.0$ & $2.0-13.0$ & $1.0-4.0$ & & & 3.0 \\
\hline Squid muscle/[73] & & 71.7 & 24.7 & & & & \\
\hline Squid viscera/[73] & 91.6 & $79.2-81.2$ & $12.7-13.4$ & & & & \\
\hline Krill/[28] & & 80.4 & 14.9 & 0.7 & & & \\
\hline Krill */[72] & 40.0 & 35.0 & 2.0 & 1.0 & & & \\
\hline Anchovy/[23] & 65.0 & 68.0 & 29.0 & 1.0 & 2.0 & & \\
\hline Fish meal */[72] & 40.0 & 22.0 & 6.0 & 2.0 & & & \\
\hline Mackerel/[74] & $8.9-12.2$ & 20.1 & 67.4 & & & & \\
\hline Water flea/[75] & & $4.1-14.4$ & $3.2-9.2$ & & & & \\
\hline
\end{tabular}

* It is not established if the reported percentage corresponds to the whole lipidic fraction of the lecithin. PC (Phosphatidylcholine), PE (Phosphatidylethanolamine), PI (Phosphatidylinositol), PA (Phosphatidic acid), PS (Phosphatidylserine), and SM (Sphingomyelin). 
The review results showed that vegetable source with the highest lecithin percentages is soybean with values of $\sim 82 \%$, whereas the lowest was sesame seeds with values of $\sim 3 \%$. Moreover, it has been reported that phosphatidylcholine is the majority phospholipid in the polar lipid fraction of lecithins followed by phosphatidylethanolamine, while the rest of phospholipids change depending on the natural sources and the applied conditions in the extraction and quantification process. [2,60,76]. In this way, lecithins' composition in vegetable sources depends significantly on the genetic variability and the quality of the seeds. While in animal sources, lecithin composition is highly dependent on the metabolic and feeding conditions [2,77] and where the sphingomyelin is unique in this source, since plants lack the necessary enzyme to synthesize such phospholipid [78]. On the contrary, the phosphatidylglycerol is exclusively of plant sources $(4.4 \%)$, because it is synthesized only in the thylakoid membranes of chloroplasts $[79,80]$. Finally, it has been reported that plant sources describe a greater variety of lecithin-rich species, while animal and marine sources are more limited. Therefore, a more specific and detailed discussion on the amounts and composition of phospholipids in lecithins from different natural sources is described below.

\subsection{Vegetable Sources of Lecithins}

Regarding lecithins of vegetable origin (Table 1), their extraction was found to be mainly associated with vegetable seeds. However, previous research indicated their potential extraction from the pulp of fruits, as it was described for avocado and olives $[29,54]$. Although there are many plant sources available for the extraction of lecithins, most of the information reported is associated with soybeans, followed by sunflower, canola, corn, rice bran, and cottonseed. In contrast, according to the U.S. Food and Drug administration (FDA), in 2018, genetically modified soybeans (GMOs) constituted $94 \%$ of all soybeans planted in that country, which is very significant data, especially when the use of lecithins from non-genetically modified sources is considered [3]. On the other hand, as mentioned previously, phosphatidylcholine is the major phospholipid labeled in all plant sources, followed by phosphatidylethanolamine and phosphatidylinositol, the proportion of which can vary depending on the source.

According to Figure 4a, the main phospholipids present in most plant species are phosphatidylethanolamine and phosphatidylcholine. However, in the case of sunflower and corn, the predominant phospholipids are phosphatidylcholine and phosphatidylinositol. For this reason, these plants are preferred for the obtention of the latter phospholipid. 


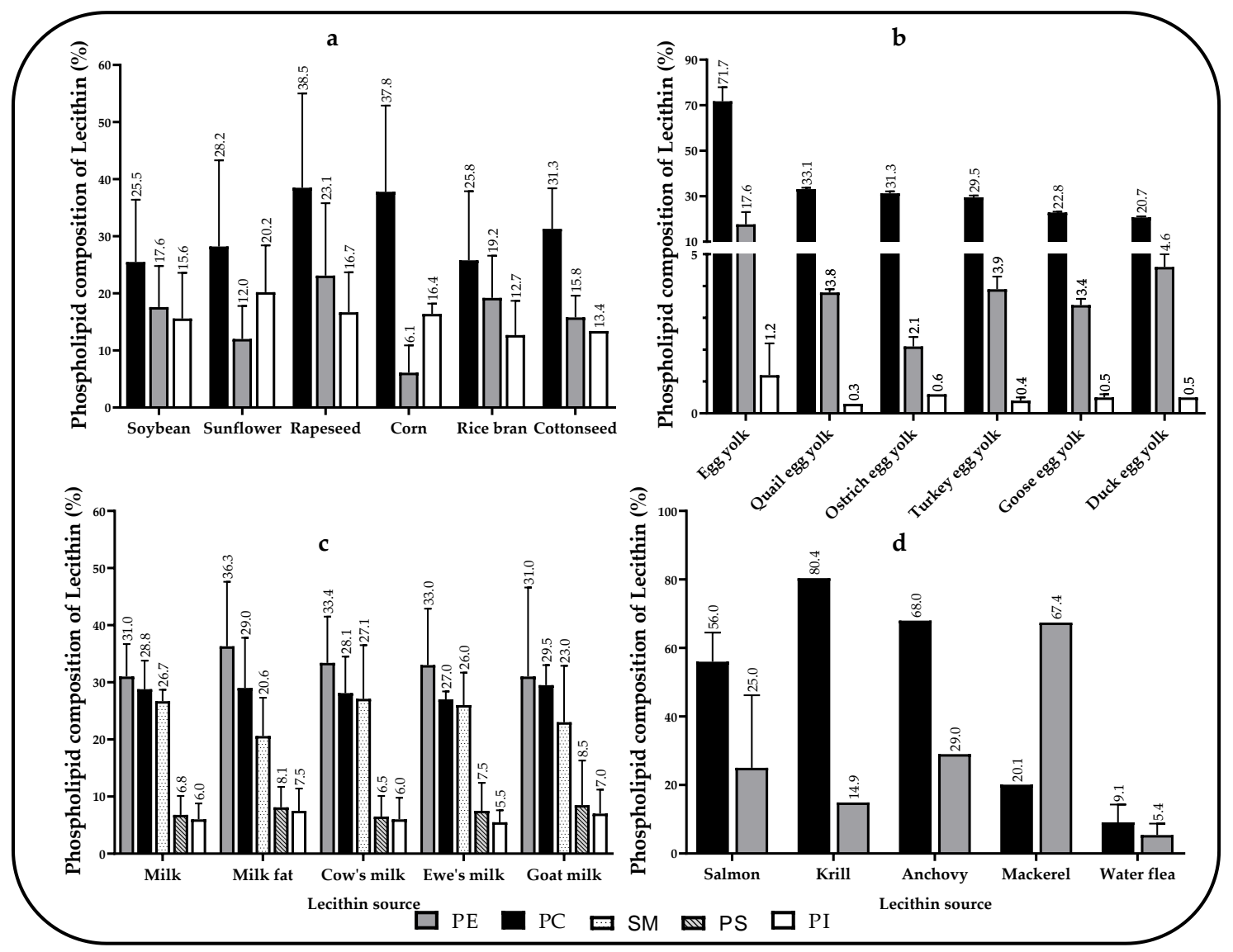

Figure 4. (a) Average composition of phospholipids in the main plant sources. (b) Average phospholipid composition in egg yolk. (c) Average phospholipid composition in milk. (d) Average composition of lecithin phospholipids from marine animals. (PE: Phosphatidylethanolamine, PC: Phosphatidylcholine, SM: Sphingomyelin, PS: Phosphatidylserine, PI: Phosphatidylinositol).

\subsection{Animal Sources of Lecithins}

Regarding lecithins of animal origin, it is reported that they are mainly extracted from egg yolk, followed by milk, as well as the brain tissue of some bovines. As for the historical aspects, egg yolk lecithins were isolated for the first time in 1850 by the French T.N., but other sources of their extraction were not explored until 1883 [81]. Moreover, egg yolk is an inexpensive and accessible source [82] and the statement suggests that its phosphatidylcholine content is higher in comparison with that of the other animal lecithins (Table 2). Furthermore, the extraction of egg yolk lecithin from different types of bird species was explored by Sinanoglou, V.J.; Strati, I.F., and Miniadis-Meimaroglou, S., where quail egg yolk was found to present the highest phosphatidylcholine content, followed by the egg yolk from ostrich and turkey, whereas the highest proportion of phosphatidylethanolamine was found in the egg yolk of ducks (Figure $4 b$ ).

Conversely, it has been widely declared that lecithins derived from milk have a higher amount of phosphatidylethanolamine than phosphatidylcholine, as well as a significant amount of sphingomyelin as shown in Figure 4c $[10,28,64,65]$. Furthermore, the phospholipid content in lecithins from milk, as well as from the fat deposits of different mammals (cow, sheep, and goat) were previously explored and compared. The results showed that lecithins from milk have a greater amount of phosphatidylcholine, phosphatidylethanolamine, and phosphatidylinositol. In contrast, lecithins from the fat deposits of such animals were rich in sphingomyelin and phosphatidylserine $[14,23,24,27,60,66-70]$. 


\subsection{Marine Animal Sources of Lecithins}

The number of studies conducted on the identification of lecithins derived from marine animal sources is very limited. However, as shown in Figure $4 \mathrm{~d}$, it is reported that marine-derived lecithins are rich in phosphatidylcholine and phosphatidylethanolamine $[13,23,28,60,70,72,74,75]$. In another report (not included in the bibliographic search), Burri, L., Hoem, N., Banni, S., and Berge, K. declared that salmon, herring, pollock, and flying fish roe contain between $38 \%$ and $75 \%$ of lecithin, with phosphatidylcholine as the main phospholipid [83] According to Figure 4d, krill and anchovy lecithins were identified to contain the highest amount of phosphatidylcholine, whereas mackerel lecithins contained the highest percentage of phosphatidylethanolamine. Contrarily, lecithins derived from water flea were stated to contain the lowest amount of these phospholipids [74,75]. Marine animal lecithins were identified to be of great interest due to their high content of $\omega-3$ fatty acids, which have been defined by providing anti-inflammatory and immunological properties [60,83-85].

\section{Uses and Applications of Lecithins}

Lecithins, as well as several of their phospholipids, have been widely used by the cosmetic, food, and pharmaceutical sectors due to their high nutritional value as well as their ability to stabilize emulsions and form liposomes. Therefore, the description of the main applications of these materials in these sectors is presented below.

\subsection{Nutritional Value}

Most of the reported information on nutritional value has been described on lecithins derived from egg yolk, followed by soybean, milk, and sunflower, respectively (Table 4). Furthermore, most of the reported information in association with the nutritional value of lecithins was related to their fatty acid profile as well as their abundance in bioactive phytochemicals $[45,86]$. Thus, their uses as an essential nutrient, a cholesterol reducer, choline supplement, and memory and physical performance booster were reported [87]. In this manner, vegetable lecithins were stated to be the most common sources of food additives, although egg yolk and milk lecithins were highly recommended for early infant nutrition due to their high content of sphingolipids as well as arachidonic and docosahexaenoic acids $[26,67,71]$. On the other hand, marine animal lecithins were identified to be of great interest due to their high content of $\omega-3$ fatty acids [60].

Furthermore, phosphatidylcholine is described to be relevant due to the choline intake $[88,89]$, being an essential nutrient for the biosynthesis of acetylcholine [89] and thereby promoting healthy metabolism and helping the reduction of inflammatory processes, apoptosis (cancer cells), cholesterol levels, and especially diseases associated with memory loss, such as Alzheimer's [7,10,88,89]. Likewise, phosphatidylethanolamine is an essential phospholipid in human nutrition that serves as a phosphatidylcholine precursor. In addition to influencing the topology of the cell membrane, it is associated with the wellbeing of the liver, as well as the promotion of cell fusion, oxidative phosphorylation, mitochondrial biogenesis, and autophagy [90-92]. In contrast, despite the limited available information on the physiological functions of the phosphatidylinositol intake [93], its importance in the transport and excretion of cholesterol in rabbits and the prevention of nonalcoholic fatty liver disease in rats was demonstrated [10,93,94]. The nutritional role of phosphatidic acid is related to its ability to produce other lipids, since it acts as a signaling lipid in cell membranes, enhancing the anabolic effects of resistance training [95-98]. Moreover, phosphatidylserine constitutes 13-15\% of all the phospholipids in the human cerebral cortex [99] and is necessary for the maintenance of the health of nerve cell membranes and myelin in addition to supporting the signal transmission process of the cerebral cortex $[100,101]$. Moreover, the presence of phosphatidylglycerol in the pulmonary surfactant is reported, which indicates its vital role in maintaining the proper performance of the activity of the lungs from birth [79]. Besides, it can be used as a treatment for the respiratory distress syndrome due to its preventive effect on the alveolar epithelial apoptosis, as well as its pro-fibrotic 
stimulation [102]. Finally, the consumption of sphingomyelin was declared to reduce the risk of colon cancer formation [10], and a previous study indicated its association with bacterial resistance to intestinal pathogens and the reduction of cholesterol absorption in intestinal mucous cells [103]. In addition, it was stated to contribute to cognitive development through its structural and functional participation in the myelination of the central nervous system [104].

Table 4. Uses and applications of lecithins derived from vegetable, animal, and marine animal sources.

\begin{tabular}{|c|c|c|c|}
\hline \multirow{2}{*}{$\begin{array}{l}\text { Origin of Lecithin } \\
\text { Sources }\end{array}$} & \multicolumn{3}{|c|}{ Reported Applications } \\
\hline & Nutritional Value & Emulsion Stabilizer & $\begin{array}{c}\text { Lipid Component of } \\
\text { Liposomes }\end{array}$ \\
\hline \multicolumn{4}{|c|}{ Vegetal Sources } \\
\hline Soybean & {$[3,10,28,31-33,61,87,105]$} & {$[3,26,31,32,35,61,87,105,106]$} & [13] \\
\hline Sunflower & {$[28,29,86,87]$} & {$[29,35,37,39,61,86,87]$} & \\
\hline Rapeseed & [87] & {$[29,35,61]$} & [13] \\
\hline Rice Bran & {$[21,44]$} & {$[21,44]$} & \\
\hline Camellia & [107] & {$[107,108]$} & \\
\hline Corn & {$[29,42]$} & [42] & \\
\hline Palm & {$[56,57]$} & [57] & \\
\hline Avocado & & {$[54]$} & \\
\hline Cotton Seed & & [106] & \\
\hline Niger seed & [53] & & \\
\hline Wheat Germ & {$[52]$} & & \\
\hline \multicolumn{4}{|c|}{ Animal Sources } \\
\hline Egg yolk & $\begin{array}{c}{[14,23,26,29,31,59-63,65} \\
73,106]\end{array}$ & {$[26,62,63,106]$} & {$[60]$} \\
\hline Milk & {$[14,29,31,67-70,87]$} & {$[60,67-70]$} & [68] \\
\hline Bovine brain & [29] & & \\
\hline \multicolumn{4}{|c|}{ Marine Animal Sources } \\
\hline Salmon & & [109] & [13] \\
\hline Fish roe & [61] & & \\
\hline Krill & [61] & & \\
\hline Squid & [73] & & \\
\hline
\end{tabular}

\subsection{Lecithins as Emulsions Stabilizers}

As for the stabilization of emulsions, previous studies demonstrated the amphiphilic nature of lecithin phospholipids to allow the reduction of the interfacial tension between the emulsion phases, facilitating the formation of small stable drops, which in turn can be electrostatically stabilized by the polar part of the lecithins over a wide $\mathrm{pH}$ range [10,44,67]. In addition, it has been reported that the high thermal stability of lecithins has allowed their use in the development of sterilizable emulsions by extreme processes, such as autoclaving [40]. Therefore, although greater use was reported to be associated with the stabilization of oil-in-water emulsions $[31,39,42,106]$, the stabilization of water-in-oil emulsions was also described for lecithins with a high content of phosphatidylinositol [108]. Besides, although a higher number of studies focused on the use of vegetable lecithins (specifically from soybean and sunflower) in comparison with that of animal lecithins, there were also several reports published on the applications of lecithins derived from egg yolks and milk (Table 4). Currently, vegetable lecithins are the most widely used emulsifiers in the food and cosmetic industry due to their 
low toxicity and high nutritional value [35,40]. Moreover, regarding the pharmaceutical sector, egg yolk lecithins were reported to be the preferred emulsifiers for parenteral oil-in-water emulsions [40], although the use of corn lecithins was also explored due to their easily metabolizable nature (as is the case for soy lecithin) [42]. Using natural phospholipids as cosmetic emulsifiers allows the production of natural cosmetic products, providing skin hydration and enhancing dermal penetration $[11,110]$.

Regarding the phospholipid characteristics of lecithins, the length of the phospholipid chain, the degree of unsaturation, and the nature of the main group have a great influence on their stabilization ability [111]. The length and the unsaturation degree of phospholipids can lead to differences in the size, shape, phase transition temperature, and hydrophilic-lipophilic balance, which may affect the droplet size of the formed emulsions, where smaller and less saturated chains in the phospholipids were reported to lead to a better stabilization in oil-in-water emulsions [112]. Furthermore, it is reported that the ionization of many of the polar groups of phospholipids were found to enhance the physical stabilization of oil-in-water emulsions $[111,113,114]$. In this way, due to the currently available great variation in the composition of lecithins, it is necessary to evaluate the phospholipid content according to the emulsion that is aimed to be stabilized.

\subsection{Lecithins to Develop Liposomes}

Liposomes are vesicular structures with a resemblance to the cell lipid membrane. They can be produced from cholesterol as well as non-toxic natural phospholipids $[115,116]$. Furthermore, due to their high biocompatibility and hydrophilic-lipophilic nature, liposomes are widely used as drug-laden systems, allowing the administration of different drugs along with their control and targeting [115-118]. Therefore, the properties of the liposomes mainly depend on the characteristics of the used lipid [116], taking into account the source of the phospholipid (natural or synthetic), the unsaturation degree, the length of the hydrocarbon chain, and the phase transition temperature [12]. Natural phospholipids are considered to be those that allow for their direct usage after they are obtained from several natural sources (as discussed in this review), whereas synthetic phospholipids must undergo a chemical process to incorporate polar groups or specific fatty acids [106]. In this way, those derived from natural sources are renewable and have a comparatively low cost, although their purification can be difficult to control in comparison with the synthetic source derivatives that have been characterized with greater stability but are more expensive and are often restricted for some pharmaceutical applications [106]. Furthermore, the structure and the permeability of the lipid bilayers are defined by the unsaturation degree and the chain length. Thus, long-chain phospholipids tend to form liposomes, whereas those with short and compact chains tend to form micelles [116]. In addition, saturated fats generate more compact and less permeable lipid bilayers than unsaturated fats [116].

Several reports are known to be published about the use of lecithins as liposome-forming compounds derived from different natural sources $[15,21-23,26,29,30,62,87,106]$ (Table 4); however, the use of purified phospholipids are preferred in the cosmetic and foodstuff sectors, whereas synthetic phospholipids are chosen for the pharmaceutical industry since these compounds can be easier characterized to meet specific quality criteria [106]. Thereby, the first cosmetic marketed as a "liposomal product" was CAPTURE ${ }^{\circledR}$, an anti-aging product from Dior, where it was stated that the use of liposomes allowed modulation of skin penetration, as well as a controlled release of argan oil [11,110]. Another interesting study showed that autoclave sterilization of emulsions stabilized with lecithins can withstand such a thermal process, which cannot be achieved with most conventional emulsifiers [12,119]. Likewise, Peter van Hoogevest and Armin Wendel explored the use of phospholipids as pharmaceutical excipients, and stated that Diltiazemuls, Limenthason, Liple, and Cleviprex are some examples of oil-in-water intravenous emulsions that use egg phospholipids as an emulsifier [106]. On the other hand, Li, J. et al. described several approved liposomal formulations in the pharmaceutical sector. Some examples are Ambisome ${ }^{\circledR}$ (Amphotericin B), authorized in 1990 in Europe; Doxil ${ }^{\circledR}$ (Doxorubicin), approved in 2007 in Canada and Europe; DaunoXome ${ }^{\circledR}$ (Daunorubicin), approved in 1996 in Europe and the USA, among others [12]. 
In summary, the main applications of natural lecithins for the cosmetic, food, and pharmaceutical sectors are based on their nutritional value and ability to stabilize emulsions, since purified or synthetic phospholipids are preferred for the formation of liposomes. These applications are possible due to their diverse lipid composition, and especially in association with their fatty acid profile, richness in bioactive phytochemicals, and high content of phospholipids.

\section{Conclusions}

This review provides updated information on the phospholipid composition of lecithins from different natural sources as well as their potential applications as a nutritional component, emulsion stabilizer, and lipid component of liposomes. Evidence shows that in recent years, various vegetable and animal sources have been explored, but those from soybean, sunflower, and egg yolk are still the most reported. In addition, although lecithin derived from marine animal sources may contain large amounts of phosphatidylcholine and phosphatidylethanolamine, there are few papers published in association with such findings. Moreover, it was shown that lecithins of natural origin have a wide range of applications in different fields, as they offer great benefits for human health as well as a significant ability to stabilize emulsified products and self-assembling structures. However, its high phospholipid variability is also important to be considered as it allows for the potential behavior of lecithins to be modified.

Author Contributions: Conceptualization, C.H.S., and M.J.A.; Methodology and Investigation, M.J.A., N.M., C.J.Y.; Formal Analysis, Writing_-Original Draft Preparation, M.J.A., N.M.; Writing—Review and Editing, C.H.S. All authors have read and agreed to the published version of the manuscript.

Funding: This research received no external funding.

Acknowledgments: The authors would like to thank to Icesi University for the support for the language editing service.

Conflicts of Interest: The authors declare no conflict of interest.

\section{References}

1. Bergfeld, W.F.; Belsito, D.V.; Hill, R.A.; Klaassen, C.D.; Liebler, D.C.; Marks, J.G., Jr.; Shank, R.C.; Slaga, T.J.; Snyder, P.W. Safety Assessment of Lecithin and Other Phosphoglycerides as Used in Cosmetics; Cosmetic Ingredient Review: Washington, DC, USA, 2015.

2. Szuhaj, B.F. Lecithins: Sources, Manufacture \& Uses; AOCS Monograph; American Oil Chemists' Society: Champaign, IL, USA, 1989; ISBN 9780935315271.

3. List, G.R. Soybean Lecithin: Food, Industrial Uses, and Other Applications. In Polar Lipids; Elsevier: Amsterdam, The Netherlands, 2015; pp. 1-33, ISBN 9781630670450.

4. Wilson, D.R. Lecithin: Benefits, Risks, and Types. Available online: https://www.medicalnewstoday.com/ articles/319260\#types-of-lecithin (accessed on 9 June 2020).

5. USDA National Organic Program Technical Evaluation Report: Lecithin-Bleached. Available online: https://www.ams.usda.gov/sites/default/files/media/Lecithin\%20bleached\%20TR\%202009.pdf (accessed on 11 June 2020).

6. Andersen, F.A. Final Report on the Safety Assessment of Trichloroethane. Int. J. Toxicol. 2008, 27, 107-138. [CrossRef]

7. Station, A.R. Impact of Dietary Phospholipids on Human Health. ALP Sci. 2008, 524, 1-15.

8. Aktas, M.; Danne, L.; Möller, P.; Narberhaus, F. Membrane lipids in Agrobacterium tumefaciens: Biosynthetic pathways and importance for pathogenesis. Front. Plant Sci. 2014, 5. [CrossRef]

9. Berg, J.M.; Tymoczko, J.L.; Stryer, L. Biochemistry, 5th ed.; W H Freeman: New York, NY, USA, 2002.

10. Küllenberg, D.; Taylor, L.A.; Schneider, M.; Massing, U. Health effects of dietary phospholipids. Lipids Health Dis. 2012, 11, 3. [CrossRef]

11. van Hoogevest, P.; Fahr, A. Phospholipids in Cosmetic Carriers. In Nanocosmetics; Springer International Publishing: Cham, Switzerland, 2019; pp. 95-140. 
12. Li, J.; Wang, X.; Zhang, T.; Wang, C.; Huang, Z.; Luo, X.; Deng, Y. A review on phospholipids and their main applications in drug delivery systems. Asian J. Pharm. Sci. 2015, 10, 81-98. [CrossRef]

13. Tehrany, E.A.; Kahn, C.J.F.; Baravian, C.; Maherani, B.; Belhaj, N.; Wang, X.; Linder, M. Elaboration and characterization of nanoliposome made of soya; rapeseed and salmon lecithins: Application to cell culture. Colloids Surf. B Biointerfaces 2012, 95, 75-81. [CrossRef]

14. Burling, H.; Graverholt, G. Milk-A new source for bioactive phospholipids for use in food formulations. Lipid Technol. 2008, 20, 229-231. [CrossRef]

15. Dayton, C.L.G.; Galhardo, F. Enzymatic Degumming. In Green Vegetable Oil Processing; Elsevier: Amsterdam, The Netherlands, 2014; pp. 107-145, ISBN 9780983057208.

16. Guiotto, E.N.; Tomás, M.C.; Diehl, B.W.K. Sunflower Lecithin. In Polar Lipids; Elsevier: Amsterdam, The Netherlands, 2015; pp. 57-75, ISBN 9781630670450.

17. Gunstone, F. Vegetable sources of lipids. In Modifying Lipids for Use in Food; Elsevier: Amsterdam, The Netherlands, 2006; pp. 11-27, ISBN 9781855739710.

18. Guo, M. Soy food products and their health benefits. In Functional Foods; Elsevier: Amsterdam, The Netherlands, 2009.

19. Hayes, D.G. Fatty Acids-Based Surfactants and Their Uses. In Fatty Acids; Elsevier: Amsterdam, The Netherlands, 2017; pp. 355-384.

20. Jafari, F.; Agh, N.; Noori, F.; Tokmachi, A.; Gisbert, E. Effects of dietary soybean lecithin on growth performance, blood chemistry and immunity in juvenile stellate sturgeon (Acipenser stellatus ). Fish Shellfish Immunol. 2018, 80, 487-496. [CrossRef]

21. Jala, R.C.R.; Prasad, R.B.N. Rice Bran Lecithin: Compositional, Nutritional, and Functional Characteristics. In Polar Lipids; Elsevier: Amsterdam, The Netherlands, 2015; pp. 35-55, ISBN 9781630670450.

22. Joshi, A.; Paratkar, S.G.; Thorat, B.N. Modification of lecithin by physical, chemical and enzymatic methods. Eur. J. Lipid Sci. Technol. 2006, 108, 363-373. [CrossRef]

23. Norn, V. Emulsifiers in Food Technology; Norn, V., Ed.; John Wiley \& Sons, Ltd.: Chichester, UK, 2014; ISBN 9781118921265.

24. Pokorný, J. Production, separation and modification of phospholipids for use in food. In Modifying Lipids for Use in Food; Elsevier: Amsterdam, The Netherlands, 2006; pp. 369-390, ISBN 9781855739710.

25. Robert, C.; Couëdelo, L.; Vaysse, C.; Michalski, M.-C. Vegetable lecithins: A review of their compositional diversity, impact on lipid metabolism and potential in cardiometabolic disease prevention. Biochimie 2020, 169, 121-132. [CrossRef]

26. Rossi, M. Use of Lecithin and Lecithin Fractions. In Bioactive Egg Compounds; Springer: Berlin/Heidelberg, Germany, 2007; pp. 229-239, ISBN 9783540378839.

27. Subra-Paternault, P.; ThongDeng, H.; Grélard, A.; Cansell, M. Extraction of phospholipids from scallop by-product using supercritical CO2/alcohol mixtures. LWT-Food Sci. Technol. 2015, 60, 990-998. [CrossRef]

28. Sun, N.; Chen, J.; Wang, D.; Lin, S. Advance in food-derived phospholipids: Sources, molecular species and structure as well as their biological activities. Trends Food Sci. Technol. 2018, 80, 199-211. [CrossRef]

29. Szuhaj, B.F.; Yeo, J.; Shahidi, F. Lecithins. In Bailey's Industrial Oil and Fat Products; Wiley: Hoboken, NJ, USA, 2020; pp. 1-86.

30. van Nieuwenhuyzen, W. Lecithin and Other Phospholipids. In Surfactants from Renewable Resources; Jhon Wiley \& Sons: Hoboken, NJ, USA, 2010; ISBN 9780470760413.

31. Wang, T. Soybean Oil. In Vegetable Oils in Food Technology; Wiley-Blackwell: Oxford, UK, 2011; pp. 59-105, ISBN 9781444332681.

32. Wang, T. Soybean: Processing. In Encyclopedia of Food Grains: Second Edition; Elsevier: Amsterdam, The Netherlands, 2015; ISBN 9780123947864.

33. Wendel, A. Lecithin. In Van Nostrand's Encyclopedia of Chemistry; Major Reference Works; John Wiley \& Sons, Inc.: Hoboken, NJ, USA, 2005; ISBN 9780471740032.

34. Yang, B.; Zhou, R.; Yang, J.-G.; Wang, Y.-H.; Wang, W.-F. Insight into the Enzymatic Degumming Process of Soybean Oil. J. Am. Oil Chem. Soc. 2008, 85, 421-425. [CrossRef]

35. Nguyen, M.T.; Van de Walle, D.; Petit, C.; Beheydt, B.; Depypere, F.; Dewettinck, K. Mapping the Chemical Variability of Vegetable Lecithins. J. Am. Oil Chem. Soc. 2014, 91, 1093-1101. [CrossRef]

36. Ghazani, S.M.; Marangoni, A.G. Healthy Fats and Oils. In Reference Module in Food Science; Elsevier: Amsterdam, The Netherlands, 2016. 
37. Julio, L.M.; Copado, C.N.; Diehl, B.W.K.; Ixtaina, V.Y.; Tomás, M.C. Chia bilayer emulsions with modified sunflower lecithins and chitosan as delivery systems of omega-3 fatty acids. LWT 2018, 89, 581-590. [CrossRef]

38. Cabezas, D.M.; Diehl, B.W.K.; Tomás, M.C. Sunflower Lecithin: Application of a Fractionation Process with Absolute Ethanol. J. Am. Oil Chem. Soc. 2009, 86, 189-196. [CrossRef]

39. Cabezas, D.M.; Madoery, R.; Diehl, B.W.K.; Tomás, M.C. Emulsifying Properties of Different Modified Sunflower Lecithins. J. Am. Oil Chem. Soc. 2012, 89, 355-361. [CrossRef]

40. Ambrosewicz-Walacik, M.; Tańska, M.; Rotkiewicz, D. Phospholipids of Rapeseeds and Rapeseed Oils: Factors Determining Their Content and Technological Significance-A Review. Food Rev. Int. 2015, 31, 385-400. [CrossRef]

41. Serna-Saldivar, S.O.; Gutiérrez-Uribe, J.A.; García-Lara, S. Phytochemical Profiles and Nutraceutical Properties of Corn and Wheat Tortillas. In Tortillas; Elsevier: Amsterdam, The Netherlands, 2015; pp. 65-96, ISBN 9780128123683.

42. Liu, H.; Liu, T.; Fan, H.; Gou, M.; Li, G.; Ren, H.; Wang, D.; Cheng, Z. Corn Lecithin for Injection from Deoiled Corn Germ: Extraction, Composition, and Emulsifying Properties. Eur. J. Lipid Sci. Technol. 2018, 120, 1700288. [CrossRef]

43. Singanusong, R.; Garba, U. Micronutrients in rice bran oil. In Rice Bran and Rice Bran Oil: Chemistry, Processing and Utilization; Elsevier: Amsterdam, The Netherlands, 2019; ISBN 9780128128282.

44. Sun, X.; Zhang, L.; Tian, S.; Yang, K.; Xie, J. Phospholipid composition and emulsifying properties of rice bran lecithin from enzymatic degumming. LWT 2020, 117, 108588. [CrossRef]

45. Manjula, S.; Subramanian, R. Laboratory Studies on Membrane Deoiling of Lecithin. J. Am. Oil Chem. Soc. 2008, 85, 573-580. [CrossRef]

46. Hernandez, E. Cottonseed. In Reference Module in Food Science; Elsevier: Amsterdam, The Netherlands, 2016.

47. Cansell, M.; Bardeau, T.; Morvan, E.; Grélard, A.; Buré, C.; Subra-Paternault, P. Phospholipid Profiles of Oleaginous Pressed Cakes Using NMR and Gas Chromatography. J. Am. Oil Chem. Soc. 2017, 94, 1219-1223. [CrossRef]

48. List, G.R. Processing and Food Uses of Peanut Oil and Protein. In Peanuts; Elsevier: Amsterdam, The Netherlands, 2016; pp. 405-428, ISBN 9781630670382.

49. Bertazzo, A.; Comai, S.; Mangiarini, F.; Chen, S. Composition of Cacao Beans. In Chocolate in Health and Nutrition; Humana Press: Totowa, NJ, USA, 2013; pp. 105-117, ISBN 9781617798030.

50. Arendt, E.K.; Zannini, E. Oats. In Cereal Grains for the Food and Beverage Industries; Elsevier: Amsterdam, The Netherlands, 2013; pp. 243-283.

51. Lafiandra, D.; Masci, S.; Sissons, M.; Dornez, E.; Delcour, J.A.; Courtin, C.M.; Caboni, M.F. Kernel Components of Technological Value. In Durum Wheat; Elsevier: Amsterdam, The Netherlands, 2012; pp. 85-124, ISBN 9780128104323.

52. Dunford, N.T. Wheat Germ Oil. In Gourmet and Health-Promoting Specialty Oils; Moreau, R.A., Kamal-Eldin, A.B.T.-G., Eds.; Elsevier: Amsterdam, The Netherlands, 2009; pp. 359-376, ISBN 978-1-893997-97-4.

53. Ramadan, M.F. Niger Seed Oil. In Gourmet and Health-Promoting Specialty Oils; Elsevier: Amsterdam, The Netherlands, 2009; pp. 283-298, ISBN 9780128043516.

54. Züge, L.C.B.; Maieves, H.A.; Silveira, J.L.M.; da Silva, V.R.; de Paula Scheer, A. Use of avocado phospholipids as emulsifier. LWT-Food Sci. Technol. 2017, 79, 42-51. [CrossRef]

55. Lim, T.K. Allium sativum. In Edible Medicinal and Non Medicinal Plants; Springer: Dordrecht, The Netherlands, 2015; pp. 210-360.

56. Panpipat, W.; Chaijan, M. Palm Phospholipids. In Polar Lipids; Elsevier: Amsterdam, The Netherlands, 2015; pp. 77-90, ISBN 9781630670450.

57. Pande, G.; Akoh, C.C.; Lai, O.-M. Food Uses of Palm Oil and Its Components. In Palm Oil; Elsevier: Amsterdam, The Netherlands, 2012; pp. 561-586, ISBN 9780128043462.

58. Venegas-Calerón, M.; Ruíz-Méndez, M.V.; Martínez-Force, E.; Garcés, R.; Salas, J.J. Characterization of Xanthoceras sorbifolium Bunge seeds: Lipids, proteins and saponins content. Ind. Crops Prod. 2017, 109, 192-198. [CrossRef]

59. Nasopoulou, C.; Gogaki, V.; Panagopoulou, E.; Demopoulos, C.; Zabetakis, I. Hen egg yolk lipid fractions with antiatherogenic properties. Anim. Sci. J. 2013, 84, 264-271. [CrossRef] 
60. Lordan, R.; Tsoupras, A.; Zabetakis, I. Phospholipids of Animal and Marine Origin: Structure, Function, and Anti-Inflammatory Properties. Molecules 2017, 22, 1964. [CrossRef]

61. van Nieuwenhuyzen, W. Production and Utilization of Natural Phospholipids. In Polar Lipids; Elsevier: Amsterdam, The Netherlands, 2015; pp. 245-276, ISBN 9781630670450.

62. Lesnierowski, G.; Stangierski, J. What's new in chicken egg research and technology for human health promotion?-A review. Trends Food Sci. Technol. 2018, 71, 46-51. [CrossRef]

63. Sunwoo, H.H.; Gujral, N. Chemical Composition of Eggs and Egg Products. In Handbook of Food Chemistry; Springer: Berlin/Heidelberg, Germany, 2015; pp. 331-363, ISBN 9783642366055.

64. Walczak, J.; Bocian, S.; Trziszka, T.; Buszewski, B. Hyphenated Analytical Methods in Determination of Biologically Active Compounds in Hen's Eggs. Crit. Rev. Anal. Chem. 2016, 46, 201-212. [CrossRef]

65. Sinanoglou, V.J.; Strati, I.F.; Miniadis-Meimaroglou, S. Lipid, fatty acid and carotenoid content of edible egg yolks from avian species: A comparative study. Food Chem. 2011, 124, 971-977. [CrossRef]

66. Metin, S.; Hartel, R.W. Milk Fat and Cocoa Butter. In Cocoa Butter and Related Compounds; Elsevier: Amsterdam, The Netherlands, 2012; pp. 365-392, ISBN 9780128043448.

67. Rombaut, R.; Dewettinck, K. Properties, analysis and purification of milk polar lipids. Int. Dairy J. 2006, 16, 1362-1373. [CrossRef]

68. Contarini, G.; Povolo, M. Phospholipids in Milk Fat: Composition, Biological and Technological Significance, and Analytical Strategies. Int. J. Mol. Sci. 2013, 14, 2808-2831. [CrossRef] [PubMed]

69. Le, T.T.; Phan, T.T.Q.; Van Camp, J.; Dewettinck, K. Milk and Dairy Polar Lipids: Occurrence, Purification, and Nutritional and Technological Properties. In Polar Lipids: Biology, Chemistry, and Technology; Elsevier: Amsterdam, The Netherlands, 2015; ISBN 9781630670450.

70. Lecomte, M.; Bourlieu, C.; Michalski, M.-C. Nutritional Properties of Milk Lipids. In Dairy in Human Health and Disease Across the Lifespan; Elsevier: Amsterdam, The Netherlands, 2017; pp. 435-452, ISBN 9780128098691.

71. Hageman, J.H.J.; Danielsen, M.; Nieuwenhuizen, A.G.; Feitsma, A.L.; Dalsgaard, T.K. Comparison of bovine milk fat and vegetable fat for infant formula: Implications for infant health. Int. Dairy J. 2019, 92, 37-49. [CrossRef]

72. Schneider, M. Marine Phospholipids and Their Applications: Next-Generation Omega-3 Lipids. In Omega-6/3 Fatty Acids; Humana Press: Totowa, NJ, USA, 2013; pp. 297-308, ISBN 9781627032155.

73. Uddin, M.S.; Kishimura, H.; Chun, B.-S. Isolation and Characterization of Lecithin from Squid (Todarodes pacificus) Viscera Deoiled by Supercritical Carbon Dioxide Extraction. J. Food Sci. 2011, 76, C350-C354. [CrossRef]

74. Asaduzzaman, A.K.M.; Chun, B.-S. Quality characteristics of lecithin isolated from deoiled mackerel ( Scomber japonicus ) muscle using different methods. J. Ind. Eng. Chem. 2015, 21, 620-626. [CrossRef]

75. Smirnov, N.N. Chemical Composition. In Physiology of the Cladocera; Smirnov, N.N., Ed.; Elsevier: Amsterdam, The Netherlands, 2017; pp. 13-38, ISBN 978-0-12-805194-8.

76. Snyder, H.E. Edible fats and oils processing: Basic principles and modern practices. Trends Food Sci. Technol. 1991, 2, 132. [CrossRef]

77. Tran, Q.; Le, T.; Pham, M.; Do, T.; Vu, M.; Nguyen, D.; Bach, L.; Bui, L.; Pham, Q. Fatty Acid, Lipid Classes and Phospholipid Molecular Species Composition of the Marine Clam Meretrix lyrata (Sowerby 1851) from Cua Lo Beach, Nghe An Province, Vietnam. Molecules 2019, 24, 895. [CrossRef]

78. Tafesse, F.G.; Ternes, P.; Holthuis, J.C.M. The Multigenic Sphingomyelin Synthase Family. J. Biol. Chem. 2006, 281, 29421-29425. [CrossRef] [PubMed]

79. Furse, S. Is phosphatidylglycerol essential for terrestrial life? J. Chem. Biol. 2017, 10, 1-9. [CrossRef] [PubMed]

80. Uphoff, A.; Hermansson, M.; Haimi, P.; Somerharju, P. Analysis of complex lipidomes. In Medical Applications of Mass Spectrometry; Vékey, K., Telekes, A., Vertes, A.B.T.-M.A., Eds.; Elsevier: Amsterdam, The Netherlands, 2008; pp. 223-249, ISBN 978-0-444-51980-1.

81. Shurtleff, W.; Aoyagi, A. History of Lecithin and Phospholipids (1850-2016): Extensively Annotated Bibliography and Sourcebook, Including Phosphatides and Liposomes; Soyinfo Center: Lafayette, CA, USA, 2016; ISBN 9781928914860 .

82. Kondratowicz, A.; Weiss, M.; Juzwa, W.; Majchrzycki, Ł.; Lewandowicz, G. Characteristics of liposomes derived from egg yolk. Open Chem. 2019, 17, 763-778. [CrossRef] 
83. Burri, L.; Hoem, N.; Banni, S.; Berge, K. Marine Omega-3 Phospholipids: Metabolism and Biological Activities. Int. J. Mol. Sci. 2012, 13, 15401-15419. [CrossRef]

84. Lordan, R.; Redfern, S.; Tsoupras, A.; Zabetakis, I. Inflammation and cardiovascular disease: Are marine phospholipids the answer? Food Funct. 2020, 11, 2861-2885. [CrossRef] [PubMed]

85. Murru, E.; Banni, S.; Carta, G. Nutritional Properties of Dietary Omega-3-Enriched Phospholipids. Biomed Res. Int. 2013, 2013, 1-13. [CrossRef] [PubMed]

86. Grompone, M.A. Sunflower and High-Oleic Sunflower Oils. In Bailey's Industrial Oil and Fat Products; John Wiley \& Sons, Ltd.: Hoboken, NJ, USA, 2020; pp. 1-54. [CrossRef]

87. van Nieuwenhuyzen, W.; Tomás, M.C. Update on vegetable lecithin and phospholipid technologies. Eur. J. Lipid Sci. Technol. 2008, 110, 472-486. [CrossRef]

88. Smith, R.E.; Rouchotas, P.; Fritz, H. Lecithin (Phosphatidylcholine): Healthy Dietary Supplement or Dangerous Toxin? Nat. Prod. J. 2016, 6. [CrossRef]

89. Duric, M.; Sivanesan, S.; Bakovic, M. Phosphatidylcholine functional foods and nutraceuticals: A potential approach to prevent non-alcoholic fatty liver disease. Eur. J. Lipid Sci. Technol. 2012, 114, 389-398. [CrossRef]

90. Calzada, E.; Onguka, O.; Claypool, S.M. Phosphatidylethanolamine Metabolism in Health and Disease. In International Review of Cell and Molecular Biology; Elsevier Inc.: Amsterdam, The Netherlands, 2016; Volume 321, pp. 29-88, ISBN 9780128047071.

91. van der Veen, J.N.; Lingrell, S.; da Silva, R.P.; Jacobs, R.L.; Vance, D.E. The Concentration of Phosphatidylethanolamine in Mitochondria Can Modulate ATP Production and Glucose Metabolism in Mice. Diabetes 2014, 63, 2620-2630. [CrossRef]

92. Li, Z.; Agellon, L.B.; Allen, T.M.; Umeda, M.; Jewell, L.; Mason, A.; Vance, D.E. The ratio of phosphatidylcholine to phosphatidylethanolamine influences membrane integrity and steatohepatitis. Cell Metab. 2006, 3, 321-331. [CrossRef]

93. Shirouchi, B.; Nagao, K.; Inoue, N.; Furuya, K.; Koga, S.; Matsumoto, H.; Yanagita, T. Dietary Phosphatidylinositol Prevents the Development of Nonalcoholic Fatty Liver Disease in Zucker $(f a / f a)$ Rats. J. Agric. Food Chem. 2008, 56, 2375-2379. [CrossRef] [PubMed]

94. Pandey, N.R.; Sparks, D.L. Phospholipids as cardiovascular therapeutics. Curr. Opin. Investig. Drugs 2008, 9, 281-285.

95. Hoffman, J.R.; Stout, J.R.; Williams, D.R.; Wells, A.J.; Fragala, M.S.; Mangine, G.T.; Gonzalez, A.M.; Emerson, N.S.; McCormack, W.P.; Scanlon, T.C.; et al. Efficacy of phosphatidic acid ingestion on lean body mass, muscle thickness and strength gains in resistance-trained men. J. Int. Soc. Sports Nutr. 2012, 9, 47. [CrossRef]

96. Joy, J.M.; Gundermann, D.M.; Lowery, R.P.; Jäger, R.; McCleary, S.A.; Purpura, M.; Roberts, M.D.; Wilson, S.M.; Hornberger, T.A.; Wilson, J.M. Phosphatidic acid enhances mTOR signaling and resistance exercise induced hypertrophy. Nutr. Metab. 2014, 11, 29. [CrossRef] [PubMed]

97. Escalante, G.; Alencar, M.; Haddock, B.; Harvey, P. The effects of phosphatidic acid supplementation on strength, body composition, muscular endurance, power, agility, and vertical jump in resistance trained men. J. Int. Soc. Sports Nutr. 2016, 13, 24. [CrossRef]

98. Fang, Y. Phosphatidic Acid-Mediated Mitogenic Activation of mTOR Signaling. Science 2001, 294, $1942-1945$. [CrossRef]

99. Kim, H.Y.; Huang, B.X.; Spector, A.A. Phosphatidylserine in the brain: Metabolism and function. Prog. Lipid Res. 2014, 56, 1-18. [CrossRef]

100. Glade, M.J.; Smith, K. Phosphatidylserine and the human brain. Nutrition 2015, 31, 781-786. [CrossRef]

101. Komori, T. The effects of phosphatidylserine and omega-3 fatty acid-containing supplement on late life depression. Ment. Illn. 2015, 7, 7-11. [CrossRef]

102. Hallman, M.; Enhorning, G.; Possmayer, F. Composition and surface activity of normal and phosphatidylglycerol-deficient lung surfactant. Pediatr. Res. 1985, 19, 286-292. [CrossRef]

103. Potočki, S. Potential health benefits of sphingolipids in milk and dairy products. Mljekarstvo 2016, 66, $251-261$. [CrossRef]

104. Schneider, N.; Hauser, J.; Oliveira, M.; Cazaubon, E.; Mottaz, S.C.; O’Neill, B.V.; Steiner, P.; Deoni, S.C.L. Sphingomyelin in brain and cognitive development: Preliminary data. ENeuro 2019, 6. [CrossRef] [PubMed]

105. Gabriele, A. Safety and efficacy of lecithins (Lipidol) for all animal species. EFSA J. 2016, 14. [CrossRef] 
106. van Hoogevest, P.; Wendel, A. The use of natural and synthetic phospholipids as pharmaceutical excipients. Eur. J. Lipid Sci. Technol. 2014, 116, 1088-1107. [CrossRef]

107. Hu, W.; Liu, P.; Liu, G.; Lu, X. Recovered Camellia oleifera lecithin by acid and enzymatic oil-degumming: Chemical composition and emulsifying properties. Int. J. Food Sci. Technol. 2020, 55, 3008-3018. [CrossRef]

108. Belayneh, H.D.; Wehling, R.L.; Cahoon, E.; Ciftci, O.N. Lipid composition and emulsifying properties of Camelina sativa seed lecithin. Food Chem. 2018, 242, 139-146. [CrossRef]

109. Belhaj, N.; Arab-Tehrany, E.; Linder, M. Oxidative kinetics of salmon oil in bulk and in nanoemulsion stabilized by marine lecithin. Process Biochem. 2010, 45, 187-195. [CrossRef]

110. Traversier, M.; Gaslondes, T.; Milesi, S.; Michel, S.; Delannay, E. Polar lipids in cosmetics: Recent trends in extraction, separation, analysis and main applications. Phytochem. Rev. 2018, 17, 1179-1210. [CrossRef]

111. Washington, C. Stability of lipid emulsions for drug delivery. Adv. Drug Deliv. Rev. 1996, 20, 131-145. [CrossRef]

112. Nii, T.; Ishii, F. Properties of various phosphatidylcholines as emulsifiers or dispersing agents in microparticle preparations for drug carriers. Colloids Surf. B Biointerfaces 2004, 39, 57-63. [CrossRef]

113. Davis, S.S. The stability of fat emulsions for intravenous administration. In Advances in Clinical Nutrition; Springer: Amsterdam, The Netherlands, 1983; pp. 213-239.

114. Hippalgaonkar, K.; Majumdar, S.; Kansara, V. Injectable Lipid Emulsions-Advancements, Opportunities and Challenges. AAPS PharmSciTech 2010, 11, 1526-1540. [CrossRef]

115. Daraee, H.; Etemadi, A.; Kouhi, M.; Alimirzalu, S.; Akbarzadeh, A. Application of liposomes in medicine and drug delivery. Artif. Cells Nanomed. Biotechnol. 2016, 44, 381-391. [CrossRef]

116. Monteiro, N.; Martins, A.; Reis, R.L.; Neves, N.M. Liposomes in tissue engineering and regenerative medicine. J. R. Soc. Interface 2014, 11, 20140459. [CrossRef]

117. Alavi, M.; Karimi, N.; Safaei, M. Application of Various Types of Liposomes in Drug Delivery Systems. Adv. Pharm. Bull. 2017, 7, 3-9. [CrossRef]

118. Çă̆daş, M.; Sezer, A.D.; Bucak, S. Liposomes as Potential Drug Carrier Systems for Drug Delivery. In Application of Nanotechnology in Drug Delivery; InTech: London, UK, 2014.

119. Pichot, R.; Watson, R.; Noron, I. Phospholipids at the Interface: Current Trends and Challenges. Int. J. Mol. Sci. 2013, 14, 11767-11794. [CrossRef]

Publisher's Note: MDPI stays neutral with regard to jurisdictional claims in published maps and institutional affiliations.

(C) 2020 by the authors. Licensee MDPI, Basel, Switzerland. This article is an open access article distributed under the terms and conditions of the Creative Commons Attribution (CC BY) license (http://creativecommons.org/licenses/by/4.0/). 